\title{
POLA INTERAKSI SOSIAL ETNIS BUGIS MAKASSAR: Dinamika Kerukunan Hidup Umat Beragama di Kota Sorong
}

\author{
The Social Interaction Pattern of the Ethnic Bugis Makassar \\ the Dynamics of the Religious Life Harmony in Sorong
}

\author{
Muhammad Rusdi Rasyid \\ Sekolah Tinggi Agama Islam Negeri Sorong \\ Jl. Sorong-Klamono KM 17 Klablim Kota Sorong \\ Email: muhammadrusdi_rasyid@ymail.com
}

Naskah diterima tanggal 19 Maret 2014. Naskah direvisi tanggal 14 April 2014.Naskah disetujui tanggal 22 April 2014

\begin{abstract}
Abstrak
Tulisan ini merupakan penelitian tentang dinamika kerukunan hidup umat beragama di Kota Sorong, dengan obyek penelitian yaitu pola interaksi sosial etnis Bugis Makassar. Pengumpulan data dilakukan dengan wawancara kepada pejabat pemerintah, tokoh masyarakat atau tokoh adat, pemimpin keagamaan dan sejumlah umat beragama. Hasil penelitian menunjukkan bahwa pola interaksi sosial etnis Bugis dengan the others yang seagama dapat dilihat; Pertama pada aktivitas ritual keagamaan, interaksi sosial terjadi pada kegiatan buka puasa bersama, shalat tarwih, pemberian zakat fitrah, hari lebaran, dan pelaksanaan ibadah qurban. Kedua, pada dimensi sosial, adanya ikatan pernikahan antar etnis yang seagama. Ketiga, pada aktor personal yang dapat dilihat pada hubungan kekeluargaan, keramahan, saling membantu dan saling menghormati. Pola interaksi sosial etnis Bugis dengan the others yang tidak seagama dapat dilihat; Pertama, pada jalinan kerja sama lintas umat melalui aktivitas keagamaan pada hari raya, dalam bentuk silaturrahim dengan melakukan kunjungan. Kedua, mengonstruksi kohesi sosial. Etnis Bugis dapat membangun sebuah hubungan dalam kehidupan masyarakat pada aspek sosial, ekonomi dan budaya. Dan Ketiga, menciptakan lingkungn kondusif dengan menguatkan ikatan emosional kekeluargaan, mengedepankan sikap moralitas dan berinteraksi dengan pola keterbukaan.
\end{abstract}

Kata kunci: pola interaksi, Bugis Makassar, kerukunan

\begin{abstract}
The research is about the dynamics of religious harmony in Sorong, with the object of research was the social interaction patterns of Bugis Makassar ethnics. The collection of the data was conducted by interviewing government officials, community leaders or traditional leaders, religious leaders and some religious people. The results showed that Bugis ethnicity social interaction with the others in the same religion occurred; Firstly, in the religious ritual activities, the social interactions happened on breaking fasting party, tarwih prayer, giving tithes, the great day (Eid), and the sacrificial worship implementation. Secondly, in the social aspect, the marriage inter-ethnic with the same religion existed. Thirdly, in the personal activity, the family relationships, hospitality, mutual support, and mutual respect were carried out. The social interaction pattern of Bugis ethnicity with others with different religion also occurred; Firstly, in the cooperation relationship among inter-religion, the religious activities happened in the great days in the form of visiting among others. Secondly, the social cohesion was constructed. Bugis ethnicity is able to build a life relationship in society in social, economic and cultural aspects. And thirdly, a conducive environment was founded by strengthening emotional relationship with kinship, moral attitudes and interaction with patterns ofopenness were promoted.
\end{abstract}

Keywords: patterns of interaction, Bugis Makassar, harmony 


\section{PENDAHULUAN}

$\mathrm{K}$ ota Sorong sebagai kota yang sedang berkembang yang memiliki distribusi penduduk terbanyak di wilayah provinsi Papua Barat sebanyak 25\% dari jumlah penduduk provinsi Papua Barat 760.422 jiwa. Dengan demikian jumlah penduduk Kota Sorong sebanyak 190.625 jiwa. Tidak heran jika Kota Sorong adalah kota yang cukup diminati oleh migran pendatang atau migran masuk dengan jumlah terbanyak di Papua Barat dengan 52,3\% (BPS Kota Sorong 2010). Namun data BPS 2012 telah meningkat tajam hingga penduduk Kota Sorong sudah mencapai sekitar 305.002 jiwa. Data ini sebagai indikasi bahwa Kota Sorong merupakan kota yang berpenduduk terbanyak di Papua Barat yang terdiri dari masyarakat multietnis dan multikultur. Kota asal migran sangat bervariasi mulai dari wilayah Indonesia Barat, misalnya; Aceh, Batak, Jawa, Sunda, Madura dan Betawi. Wilayah Indonesia Tengah, misalnya; Dayak, Banjar dan wilayah Timur, misalnya; Ambon, Kei, Bugis, Makassar, Mandar, Tator, Manado, Buton dan suku-suku dari Papua misalnya; Ayamaru, Moi, Kokoda, Serui. Dari berbagai etnis tersebut telah berkumpul dan menyatu di Kota Sorong sebagai masyarakat pluralis. Interaksi dan komunitas yang berbaur di kota ini berasal dari berbagai latar belakang budaya dan karakter yang berbeda, sehingga dapat menimbulkan gesekan dan konflik sosial sebagaimana yang pernah terjadi di berbagai wilayah di Indonesia.

Masing-masing etnis memiliki falsafah hidup dengan budaya yang melekat pada dirinya dengan ciri khusus. Dari segi religiusitas, nampaknya etnis tertentu memeluk agama mayoritas, misalnya etnis Bugis, Padang dan Jawa meskipun tidak semua masyarakatnya beragama Islam tetapi telah melekat padanya identitas keagamaan yang dipeluknya. Etnis Toraja, Batak dan Minahasa meskipun tidak semuanya beragama Kristen namun telah melekat padanya agama Kristen yang dianutnya. Begitu pun etnis Bali yang mayoritas masyarakatnya memeluk agama Hindu, etnis Cina dengan Budha atau Khonghucu. Masyarakat Indonesia adalah masyarakat plural (plural society), dari segi etnis, misalnya suku Melayu, Jawa, Madura, Bugis, Makassar, Toraja, Mandar, Sunda, Batak, dan suku-suku di Papua. Pluralisme masyarakat adalah salah satu ciri utama masyarakat "multikultural" yaitu suatu konsep yang menunjuk kepada suatu masyarakat yang mengedepankan pluralisme budaya (Lubis 2005:2). Dengan demikian Kota Sorong sebagai kota dengan penduduk yang pluralistik mengandung berbagai budaya dari setiap etnis yang menetap dan berinteraksi di masyarakat.

Interaksi sosial antar etnik migran dan non migran secara alami terjadi di kota atau desa di wilayah Indonesia, tidak terkecuali Kota Sorong yang berpenduduk multietnis dan multikultur. Dalam interaksi sosial, kelompok minoritas seringkali menjadi obyek prejudice dan diskriminasi. Sebaliknya, kelompok minoritas boleh jadi menguasai sektor ekonomi suatu etnis mayoritas. Hal ini dapat dilihat di Indonesia, orang Cina dapat lebih menguasai perekonomian Indonesia dibanding pribumi sendiri. Etnik pendatang antar etnik pribumi, seringkali terjadi interaksi sosial dalam kehidupan sehari-hari. Interaksi ini bisa menjadi ajang komunikasi integrasi yang semakin akrab, tetapi boleh jadi akan berproses yang bermuara pada konflik antar etnis yang disebabkan berbagai faktor, di antaranya adalah faktor agama atau faktor sosial ekonomi.

Etnis Bugis adalah salah satu etnis yang banyak dijumpai di Kota Sorong dengan berbagai profesi. Etnis ini konon sudah sejak lama migrasi ke tanah Papua dan selanjutnya diikuti oleh keluarga dan kerabatnya. Etnis Bugis berasal dari daerah provinsi Sulawesi Selatan, mendiami sebagian besar dari pulau Sulawesi bagian Selatan. Penduduk provinsi Sulawesi Selatan terdiri dari empat suku bangsa, yaitu: Bugis, Makassar, Mandar dan Tator (Mattulada dalam Koentjaraningrat, 1999:266). Selanjutnya dalam tulisan ini, etnis Makassar, Mandar dan Tator cukup diwakili dengan menyebut etnis Bugis. Pada konteks ini ketika orang di perantauan menyebut Bugis maka orang akan segera paham bahwa yang dimaksud orang Bugis adalah etnis mayoritas Islam yang berasal dari Sulawesi Selatan yang di dalamnya telah menyatu etnis Makassar, Mandar dan Tator.

Pengetahuan tentang pola interaksi sosial antara etnis Bugis dengan etnis lain atau kelompok masyarakat Bugis dengan kelompok masyarakat lain sangat penting pada masyarakat Kota Sorong yang pluralistik. Interaksi sosial berlangsung antara 
berbagai etnis pendatang dan etnis pribumi, serta interaksi antar agama yang berbeda. Pola interaksi etnis Bugis ini sangat penting diketahui, mengingat etnis Bugis memiliki kultur tersendiri dalam berinteraksi dengan sesama etnis begitu juga dalam berinteraksi dengan etnis lain. Pola interaksi yang menyimpang atau negatif dapat mengakibatkan bahaya laten, sebagaimana masih segar dalam ingatan kita tentang konflik yang terjadi di berbagai wilayah di Indonesia seperti konflik etnis yang bernuansa keagamaan misalnya di Ambon tahun 1999, Maluku, Poso, Bangkalan, Sambas dan Papua (Hakim, 2006:61).

Etnis Bugis secara turun-temurun dalam kehidupan sehari-hari masih terikat oleh sistem norma dan aturan-aturan adat yang keramat dan sakral yang dikenal dengan panngaderreng (atau panngadakkang dalam bahasa Makassar). Sistem adat keramat orang Bugis berdasarkan pada lima unsur pokok yaitu: Ade' ( $a d a^{\prime}$ dalam bahasa Makassar), Bicara, Rapang, Wari', dan Sara' kemudian dibarengi dengan martabat dan harga diri yang terkandung dalam konsep siri' (Mattulada dalam Koentjaraningrat, 1999:277). Hal yang menarik bagi etnis Bugis bila dalam berinteraksi dengan masyarakat multi etnis di kota perantauan Sorong tetap konsisten dalam melakukan interaksi masih dilandasi dengan budaya panngaderreng.

Berdasarkan latar belakang fenomena tersebut maka yang menarik untuk dikaji lebih jauh adalah bagaimana pola interaksi sosial keagamaan etnis Bugis Makassar pada masyarakat Kota Sorong. Riset ini membahas tiga persoalan utama. Pertama, bagaimana pola interaksi sosial keagamaan etnis Bugis dengan etnis lain yang seagama di kota Sorong? Kedua, bagaimana pola interaksi sosial keagamaan etnis Bugis dengan etnis lain yang tidak seagama di kota Sorong? Ketiga, kajian ini juga akan memetakan sejauhmana potensi konflik dan potensi integrasi etnis Bugis dengan etnis lain di lingkungan masyarakat kota Sorong?

Riset ini diharapkan berguna untuk kepentingan teoritis dan praktis. Secara teoritis riset ini dapat berguna untuk; Pertama, memberikan kontribusi yang bermanfaat secara teoritis, metodologis, dan empirisbagikepentingan akademis dalam bidang pengkajian sosial keagamaan. Kedua, hasil riset ini dapat dijadikan suatu pola dan strategi dalam peningkatan hubungan posistif antar etnis dalam wilayah NKRI. Ketiga, dapat dijadikan sebagai alternatif model sistem interaksi sosial keagamaan yang posisitf. Secara praktis riset ini diharapkan berguna untuk dijadikan; Pertama, menjadikan pedoman dalam berinteraksi dengan multietnis di wilayah Sorong untuk menghindari disintegrasi bangsa. Kedua, bahan masukan bagi pemerintah terutama penegak hukum dan unsur Kementerian Agama dalam merencanakan, melaksanakan, dan melakukan pengawasan serta mengevaluasi sistem interaksi yang berlangsung di masyarakat Kota Sorong. Ketiga, sebagai masukan dalam memberi bahan pembelajaran berbasis interaksi sosial keagamaan pada pelatihan-pelatihan yang diselenggarakan oleh pemerintah dan masyarakat.

\section{Tinjauan Pustaka \\ Teori Fungsionalisme Struktural}

Teori yang digunakan sebagai pendekatan dalam menjawab permasalahan tersebut, yaitu; teori fungsionalisme struktural, salah satu tokohnya adalah Talcott Parsons (1902), ia berpendapat bahwa masyarakat sebagai sistem sosial paling tidak harus memiliki empat fungsi imperatif yang sekaligus merupakan karakteristik suatu sistem. Fungsi di sini bermakna kumpulan kegiatan yang ditujukan ke arah pemenuhan kebutuhan sistem. Keempat fungsi tersebut biasa dikenal dengan singkatan "AGIL" yang merupakan singkatan dari fungsi A (Adaptacion); yaitu fungsi adaptasi merupakan sistem untuk mempertahankan sumber-sumber penting dalam sistem menghadapi external demands, sistem harus bisa menyesuaikan diri dengan lingkungan juga dapat menyesuaikan lingkungan untuk kebutuhannnya. Fungsi G (Goal Attainment); yaitu fungsi pencapaian tujuan ketika sistem memprioritaskan tujuan dan memobilisasi sumber daya untuk mencapai tujuan. Fungsi I (Integration); yaitu fungsi integrasi merupakan proses yang terjadi di internal sistem yang mengkoordinasi inter-relationsheep berbagai subsistem. Fungsi L (Latency); yaitu fungsi pemeliharaan pola merupakan proses ketika sistem memelihara motivasi dan kesepakatan sosial dengan menggunakan internal tensions (sosial control). Sebuah sistem harus memelihara dan memperbaiki motivasi pola-pola individu dan kultural (Haryanto, 
2012:20). Terlepas dari kontroversi teori ini digunakan untuk mendeskripsikan konteks sistem sosial yang berlaku pada masyarakat Kota Sorong sebagai sebuah masyarakat perkotaan yang pluralistik. Teori ini cenderung berlaku dalam kondisi keseimbangan (ekuilibrium) meskipun setiap sistem sosial tidak tertutup kemungkinan mengalami perubahan sosial.

\section{Pola Interaksi Sosial}

Konsep pola interaksi sosial etnis Bugis di Kota Sorong didasarkan pada konsep interaksi sosial menurut Soerjono Soekanto yakni hubungan sosial yang dinamis antara orang-orang perorangan, antara kelompok-kelompok manusia. Ketika dua orang bertemu maka interaksi sosial dimulai saat itu. Mereka saling menegur, berjabat tangan, saling berbicara, atau bahkan mungkin berkelahi atau bertemu muka dan tidak saling bicara. Aktifitas semacam itu merupakan bentuk-bentuk interaksi sosial (Soekanto, 2000:67). Interaksi juga dapat diartikan sebagai stimulasi dan tanggapan antar manusia, atau hubungan timbal balik antara pihakpihak tertentu (Mustafa dan Elisa, 2011:144). Dua orang yang bertemu atau berpapasan di jalan juga dapat disebut interaksi, hal ini karena keduanya memiliki kesan dengan adanya stimulasi dari kedua pihak, baik dalam bentuk gerak, suara jalan atau aroma minyak wangi dari salah satu dari keduanya. Demikian ini akan menimbulkan kesan dalam pikiran seseorang.

Kata "pola" dapat bermakna sebagai sistem, cara kerja, bentuk (struktur), misalnya pola budaya adalah segala rangkaian dari unsur-unsur yang menjadi ciri-ciri yang paling menonjol dari suatu kebudayaan; pola perilaku adalah wujud dari suatu rangkaian perilaku manusia atau golongan orang sehingga tampak dan dapat dideskripsi; pola sosial adalah segala rangkaian berbagai unsur tertentu yang sudah mantap yang terdapat dalam suatu gejala masyarakat (Kamus Bahasa Indonesia, 2008:1198). Sementara kata sosial adalah sesuatu yang berhubungan dengan masyarakat (kamus Bahasa Indonesia, 2008:1496). Pada kajian ini pola interaksi sosial berusaha mendeskripsikan bentukbentuk hubungan timbal balik antar individu atau kelompok etnis Bugis dengan etnis lain dalam masyarakat yang ada di Kota Sorong.

Etnis Bugis yang ada di Kota Sorong merupakan etnis migran yang datang ke Kota
Sorong dengan membawa budayanya dalam berinteraksi dengan etnis lain. Etnis Bugis tersebut bergabung dalam satu lembaga kerukunan yaitu Kerukunan Keluarga Sulawesi Selatan yang biasa disingkat dengan KKSS. Lembaga ini dibentuk di berbagai daerah di luar pulau Sulawesi Selatan yang salah satu tujuannya sebagai wadah ajang silaturrahmi. Karenanya dalam kajian ini etnis Bugis cukup mewakili etnis Makassar, Mandar dan Tator. Hal ini karena keempat etnis tersebut memiliki latar belakang budaya yang bisa dikatakan hampir sama.

Kesamaan dan perbedaan agama dan budaya suatu etnis merupakan faktor utama dalam mempengaruhi proses interaksi sosial seseorang. Interaksi sosial yang terjadi antara dua etnis yang memiliki kesamaan keyakinan atau nilai-nilai agama akan lebih mudah menciptakan hubungan harmonis dibandingkan dengan dua etnis yang memiliki banyak latar belakang perbedaan nilai, agama dan budaya. Karenanya dalam kajian ini konsep interaksi akan fokus pada kajian etnis Bugis yang mayoritas beragama Islam berinteraksi dengan sesama etnis migran, yaitu etnis Jawa yang juga mayoritas beragama Islam di Kota Sorong, etnis Bugis berinteraksi dengan etnis lokal Papua kota Sorong yaitu etnis Moi, Kokoda dan Ayamaru yang memiliki latar belakang budaya dan agama yang berbeda.

\section{METODE PENELITIAN}

Berdasarkan pada latar belakang permasalahan tersebut, maka peneliti mengkaji obyek penelitian ini dengan menggunakan pendekatan studi kasus yang bertujuan untuk menghasilkan uraian secara cermat tentang suatu program, peristiwa, aktivitas, proses, atau sekelompok individu (Creswell, 2010:20). Selanjutnya ada dua alasan mengapa pendekatan ini dianggap lebih tepat digunakan untuk mencapai tujuan penelitian ini, yaitu; Pertama, penelitian ini dimaksudkan untuk memahami proses interaksi sosial suatu peristiwa yang terjadi pada obyek penelitian. Kedua, mengeksplorasi sistematika atau pola interaksi yang terjadi pada objek penelitian. Obyek penelitian ini dilakukan pada kondisi yang alamiah (natural setting), obyek yang alamiah adalah obyek yang berkembang apa adanya, tidak dimanipulasi oleh peneliti dan kehadiran peneliti tidak mempengaruhi dinamika pada obyek tersebut. Berdasarkan hal tersebut penelitian ini juga sebut penelitian kualitatif (Sugiyono, 2011:8). 
Untuk pengumpulan data, peneliti menggunakan teknik pengumpulan data triangulasi, yaitu sebagai teknik pengumpulan data yang bersifat menggabungkan dari berbagai teknik pengumpulan data dan sumber data yang telah ada. Peneliti menggunakan observasi, wawancara mendalam dan dokumentasi untuk sumber data yang sama secara serempak (Sugiyono, 2011:241). Observasi ini bersifat non-partisipatif, dengan melakukan pengamatan terhadap realitas yang terjadi, agar memperoleh gambaran yang lebih lengkap mengenai permasalahan yang sedang dikaji. Wawancara dilakukan terhadap subyek penelitian untuk mendapatkan informasi mengenai pola interaksi etnis Bugis dengan etnis lain yang seagama dan etnis yang tidak seagama. Untuk mendapatkan informasi penggalian informasi melalui para informan antara lain; pejabat pemerintah, tokoh masyarakat atau tokoh adat, pemimpin keagamaan dan sejumlah umat beragama. Selanjutnya data dianalisis dengan menggunakan metode analisis kualitatif kemudian diinterpretasi dengan menggunakan pendekatan studi kasus melalui data emik yang berdasarkan pada agama dan budaya etnis individu atau kelompok.

\section{PEMBAHASAN}

\section{Sekilas Kota Sorong}

Asal mula kata Sorong berasal dari kata soren. Soren dalam bahasa Biak Numfor yang berarti laut yang dalam dan bergelombang. Kata Soren digunakan pertama kali oleh suku Biak Numfor yang berlayar pada zaman dahulu dengan perahu-perahu layar dari satu pulau ke pulau lain hingga tiba dan menetap di Kepulauan Raja Ampat. Suku Biak Numfor inilah yang memberi nama "Daratan Maladum" dengan sebutan Soren yang kemudian dilafalkan oleh para pedagang Thionghoa, Misionaris dari Eropa, Maluku dan Sanger Talaut dengan sebutan Sorong (Profil Kota Sorong, 2004:5). Kota Sorong dikenal dengan istilah Kota Minyak sejak masuknya para surveyor minyak bumi dari Belanda pada 1908. Atribut peninggalan sejarah Kota Sorong sebagai salah satu kota yang terkenal dengan sejarah Heritage Nederlands Neuw Guinea Maschcapeij (NNGPM) atau Kota yang penuh dengan sisa-sisa peninggalan sejarah bekas perusahaan minyak milik Belanda.

Kota Sorong sangatlah strategis karena merupakan pintu keluar masuk Provinsi Papua dan Kota Persinggahan. Kota Sorong juga merupakan Kota industri, perdagangan dan jasa, karena Kota
Sorong dikelilingi oleh Kabupaten-Kabupaten yang mempunyai Sumber Daya Alam yang sangat potensial sehingga membuka peluang bagi investasi dalam maupun luar negeri untuk menanamkan modalnya. Kota Sorong pada mulanya merupakan salah satu kecamatan yang dijadikan pusat pemerintahan Kabupaten Sorong. Namun dalam perkembangannya telah mengalami perubahan sesuai Peraturan Pemerintah No. 31 Tahun 1996 tanggal 3 Juni 1996 menjadi Kota Administrasi Sorong. Selanjutnya berdasarkan Undang-Undang No.45 Tahun 1999 Kota Administratif Sorong ditingkatkan statusnya menjadi daerah otonom sebagai Kota Sorong. Kemudian pada tanggal 12 Oktober 1999 bertempat di Jakarta dilaksanakan pelantikan Pejabat Walikota Sorong Drs.J.A.Jumame dan selanjutnya secara resmi Kota Sorong terpisah dari Kabupaten Sorong pada tanggal 28 Februari 2000 (Profil Kota Sorong, 2004:6). Dengan demikian kini Kota Sorong telah mengalami proses dinamisasi pembangunan selama 13 tahun terakhir.

\section{Pola Interaksi Sosial Etnis Bugis dengan The Others Yang Seagama Aktivitas Keagamaan}

Pengajian, pola interaksi sosial etnis Bugis dengan the others yang seagama dapat dijumpai dalam kegiatan pengajian (majelis taklim). Majelis taklim merupakan sebuah kelompok pengajian yang bertujuan untuk dapat bekerja sama memperdalam ajaran agama. Selain itu, majelis taklim juga dapat menyambung keakraban antara sesama masyarakat muslim lintas etnis. Bentuk kegiatan majelis taklim yang diselenggarakan di Kota Sorong tidak hanya terdiri dari etnis Bugis saja tetapi diselenggarakan secara bersama-sama oleh beberapa etnis, antara lain etnis Jawa, Ternate, Maluku, Sunda dan lainnya. Hal ini terjadi tidak hanya berkumpul di masjid yang mayoritas etnis Bugis, namun juga sering dilaksanakan di masjid yang mayoritas etnis lain yang seagama. Konteks sosial ini menjadi indikasi kuatnya kebersamaan antar etnis, bersatu dan senantiasa menjalin kerja sama di bidang keagamaan antara mereka. Hal ini dikemukakan oleh $\mathrm{Hj}$. Fatimah dalam sebuah wawancara, dikatakan bahwa kegiatan pengajian majelis taklim Al-Azhar diselenggarakan tidak hanya satu etnis, tetapi terdiri beberapa etnis (wawancara, tanggal 7 November 2013). Hal ini berarti bahwa kegiatan majelis taklim menjadi wadah interaksi yang mempererat hubungan individu atau kelompok terhadap 
individu yang lain untuk menjalin kebersamaan dan kerja sama lintas umat. Maka implikasinya adalah sebuah interaksi kerukunan akan tercipta dan tatanan sosial berjalan dengan kondusif.

Aktifitas ritual keagamaan yang lain dapat dilihat pada bentuk pengajian rumahan. Pengajian rumahan adalah pengajian antar rumah yang berada pada satu wilayah tingkat RW. Pengajian ini bertujuan untuk memperluas wawasan keagamaan warga muslim, selain itu pengajian ini juga bertujuan untuk mempererat tali silaturrahim di antara warga masyarakat yang berada di wilayah pemukiman yang sama. Bentuk kegiatan pengajian rumahan ini diselenggarakan dari rumah ke rumah warga secara bergantian. Warga yang terlibat dalam pengajian rumahan ini tidak hanya berasal dari etnis Bugis saja melainkan terdiri dari beberapa etnis yang beragama Islam. Warga secara bersama-sama saling membantu dalam mempersiapkan pengajian tersebut, diantaranya mengundang ustazah atau ustaz, mempersiapkan konsumsi dan mengatur tempat pengajian. Entitas ini menunjukkan bahwa kebersamaan dan kerja sama antar etnis sudah terjalin secara mapan. Hal ini menjadi indikator kokohnya persaudaraan antar muslim tanpa melihat perbedaan etnis. Sebagaimana diungkapkan oleh Ketua Ikatan Wanita Sulawesi Selatan, Hj. Fatimah bahwa kegiatan pengajian rumahan diadakan minimal dua kali setiap bulan (wawancara, 7 November 2014). Hal ini berarti bahwa kegiatan Pengajian rumahan menjadi salah satu wadah interaksi antar etnis yang mempererat hubungan silaturrahim antar individu atau kelompok dari berbagai etnis yang seagama. Olehnya itu kegiatan ini dapat berimplikasi pada sebuah hubungan emosional yang kuat, selain itu juga berdampak pada lahirnya kerukunan dan terciptanya kawasan yang kondusif.

Selain itu pola interaksi sosial etnis Bugis dengan the others yang seagama dapat dijumpai pada aktivitas ritual keagamaan dalam bentuk pengajian tabligh akbar. Tabligh akbar merupakan kegiatan yang dilakukan dengan tujuan menyampaikan ajaran-ajaran Islam yang diterima dari Allah swt. kepada umat manusia agar dijadikan pedoman hidup agar memperoleh kebahagian di dunia dan akhirat. Selain itu tabligh akbar juga bertujuan untuk mempererat ukhuwah islamiah dikalangan warga muslim Kota Sorong. Sebagaimana tabligh akbar yang baru saja terselenggara di Masjid Al-Akbar Kota Sorong pada hari Ahad tanggal 27 Oktober 2013 dengan menghadirkan muballigh Nasional.
Terdapat beberapa etnis Bugis dan etnis lain terlibat dalam menyukseskan kegiatan akbar ini dengan bekerja bersama-sama dan saling berbagi tugas. Pada konteks ini telah terjadi pola interaksi sosial antara etnis Bugis dengan etnis lain yang seagama. Hal tersebut juga menunjukkan bahwa etnis Bugis telah membaur dan menyatu dengan etnis lain dengan tujuan yang sama. Sebagaimana teori fungsionalisme struktural yang dikemukakan oleh Talcott Parson bahwa untuk memenuhi kebutuhan individu atau kelompok, maka harus memiliki empat fungsi di antaranya adalah fungsi integrasi (Campbell, 1994:255). Aktivitas ini menunjukkan bahwa tabligh akbar merupakan salah satu wadah interaksi sosial etnis Bugis dengan etnis lain sebagai upaya melebur dan menyatu dengan etnis lain. Karenanya kegiatan ini dapat berimplikasi pada terciptanya hubungan yang harmonis dan suasana keakraban.

Hari Raya Islam, pola interaksi sosial etnis Bugis dengan the others yang seagama dapat dijumpai pada aktifitas ritual keagamaan pada rangkaian hari raya besar Islam. Sebulan sebelum lebaran Idul Fitri bagi umat Islam didahului puasa bersama sebagai bentuk ibadah kepada sang Khalik. Setelah seharian puasa umat muslim berbuka puasa sebagai tanda berakhirnya puasa pada hari tersebut. Buka puasa merupakan salah satu rangkaian kegiatan ibadah bulan Ramadhan yang dilakukan masyarakat muslim dengan tujuan saling berbagi makanan dan minuman. Buka puasa ini biasa dilakukan secara berjamaah setelah umat muslim melakukan puasa seharian. Buka puasa bersama dilakukan dalam bentuk kerja sama antar warga. Setiap warga muslim mendapat jadwal membawa makanan buka puasa ke masjid. Etnis Bugis muslim turut melakukan hal yang sama sebagai bentuk kecintaan pada kegiatan keagamaan bersama etnis yang lain. Setiap warga merasa gembira ketika mendapat jadwal membawa makanan buka puasa ke masjid. Masjid inilah sebagai wadah interaksi sosial antar etnis dalam melakukan buka puasa bersama. Ada beberapa faktor yang menyebabkan warga merasa senang melakukan buka puasa bersama di masjid, Pertama adalah warga muslim memahami bahwa dengan menyumbang makanan kepada orang yang berpuasa akan medapatkan pahala sebagaimana pahala orang yang berpuasa (Nawawi, 2010:426). Faktor Kedua adalah, dengan berbuka puasa bersama di masjid akan mempererat rasa persaudaraan antar etnis yang seagama (Hasyim Anas, 13 November 2014). Hal ini menunjukkan 
indikator kuatnya kebersamaan dan persatuan antar etnis seagama.Kegiatan buka puasa bersama ini berdampak pada terwujudnya kerukunan hidup antar etnis di Kota Sorong.

Interaksi sosial etnis Bugis dengan the others yang seagama juga dapat dijumpai pada aktifitas ritual keagamaan pada shalat tarwih. Shalat tarwih sebagai aktivitas ritual keagamaan merupakan kegiatan yang dilakukan umat muslim pada bulan Ramadhan. Tujuan ibadah ini adalah untuk menunaikan salah satu ajaran Islam. Pada bulan Ramadhan umat muslim di Kota Sorong ramai melakukan shalat tarwih bersama di seluruh masjid. Masjid Al-Akbar sebagai masjid terbesar di Kota Sorong ramai dikunjungi umat muslim dari berbagai etnis, berkumpul untuk menunaikan shalat tarwih berjamaah. Sebelum melakukan shalat tarwih, jamaah terlebih dahulu menunaikan shalat Isya dan dilanjutkan dengan ceramah agama. Para penceramah pun berlatar belakang etnis yang berbeda, bahkan beberapa etnis Bugis sering diundang untuk melakukan ceramah agama di masjid besar tersebut. Shalat tarwih di masjid ini merupakan salah satu faktor penting terjadinya interaksi antar etnis. Keterlibatan etnis Bugis dalam kegiatan keagamaan ini baik sebagai penceramah, pengurus, panitia ataupun sebagai jamaah rutin shalat tarwih menunjukkan bahwa etnis Bugis mampu beradaptasi dengan etnis lain. Dampaknya bahwa etnis Bugis dapat diterima di kalangan etnis lain yang bermuara pada terjalinnya hubungan yang harmonis di antara umat beragama.

Interaksi sosial etnis Bugis juga dapat dijumpai pada proses pembagian zakat fitrah. Zakat fitrah adalah salah satu bentuk rangkaian aktivitas ibadah bulan Ramadhan. Zakat fitrah diberikan kepada kaum dhuafa atau orang yang tidak mampu dengan tujuan meringankan beban kehidupan seseorang. Hampir semua masjid yang ada di Kota Sorong dibentuk panitia yang pengurus zakat fitrah. Zakat fitrah ini dikumpul oleh panitia lalu membagikannya kepada orang-orang yang berhak menerima secara adil tanpa membeda-bedakan etnis tertentu. Format kepanitiaan pembagian zakat fitrah tidak hanya terdiri dari satu etnis saja, tetapi terdiri dari berbagai etnis yang ada di Kota Sorong, di antaranya adalah etnis Jawa, Sunda, Maluku, Bugis Makssar, Buton dan lainnya. Zakat fitrah yang dibagikan kepada kaum dhuafa terdiri dari beberapa bentuk. Pertama, panitia mendatangi kediaman kaum dhuafa dan memberikan zakat fitrah. Kedua, kaum dhuafa diundang datang ke masjid untuk diberikan zakat fitrah.Ketiga, panitia menitipkan zakat fitrah itu kepada tetangga atau keluarga kaum dhuafa jika panitia tidak sempat bertemu dengan kaum dhuafa (wawancara, 7 November 2013). Faktor konteks sosial keagamaan ini menjadi indikasi kuatnya entitas ini bersatu dan senantiasa menjalin kerja sama dalam memberdayakan kaum dhuafa. Hal ini dikuatkan oleh teori Talcott Parson bahwa sistem harus memiliki empat fungsi, di antaranya adalah fungsi integrasi dan latency (Campbell, 1994:225). Hal ini menunjukkan bahwa etnis Bugis mampu berintegrasi dalam bentuk kerja sama dengan etnis lain. Selain itu faktor latency juga dapat diwujudkan dengan bentuk mempertahankan keutuhan dan persatuan di antara etnis yang lain. Karena itu, kegiatan sosial keagamaan zakat fitrah berdampak pada interaksi sosial yang harmonis antar etnis dan antar pemberi zakat dan penerima zakat.

Bagi kaum muslim ada dua hari lebaran, yaitu hari raya Idul fitri dan hari raya Idul Adha. Kedua hari ini merupakan hari kegembiraan umat muslim. Pada hari raya Idul fitri umat muslim serentak mengunjungi lapangan yang telah dipersiapkan untuk melaksanakan shalat dan lapangan hocky sebagai pusat kegiatan masyarakat Kota Sorong.Setiap tahun dijadikan tempat shalat Ied umat muslim dari berbagai etnis. Setidaknya ada dua bentuk interaksi sosial keagamaan yang ditampakkan etnis Bugis pada hari raya ini. Pertama, ketika berada di lapangan, mereka saling bersalam-salaman usai menunaikan shalat ied. Kedua, ketika mereka saling mengunjungi tetangga untuk bermaaf-maafan. Konteks sosial keagamaan ini menjadi indikasi kearifan etnis Bugis dalam menjaga dan mempertahankan kerukunan antar etnis seagama. Hal ini dikuatkan oleh Talcott Parson dengan teori Latency bahwa sistem akan mencapai tujuannya jika mampu mempertahankan interaksi yang harmonis (Ritzer, 2011:410).

Pola interaksi sosial lainya dapat dijumpai pada aktivitas ritual keagamaan pada saat qurban. Qurban adalah salah satu bentuk kegiatan ritual keagamaan yang dilakukan umat Islam sebagai simbol ketaatan menjalankan sunnah nabi. Usai shalat Idul Adha tidak sedikit umat muslim melakukan pemotongan hewan qurban, terutama sapi dan kambing. Sebagiamana yang dilakukan panitia qurban masjid Al-Hakim kelurahan Klawuyuk Kota Sorong, telah berqurban sebanyak sembilan ekor sapi. Pada ritual ini terdapat beberapa bentuk interaksi sosial keagamaan, di antaranya; 
Pertama, Panitia qurban yang terdiri dari multi etnis bekerja sama mengatur warga yang ingin berqurban. Kedua, panitia beriteraksi dengan warga multi etnis yang berhak menerima daging qurban. Aktivitas ritual keagamaan ini sebagai indikasi kuatnya integrasi etnis Bugis sebagaimana dikuatkan oleh Muhammad Satir, bahwa etnis Bugis di lingkungan masjid Al-Hakim Klawuyuk Kota Sorong mudah bergaul dan akrab dengan etnis lain. Hal ini tampak pada beberapa kesempatan etnis Bugis bercengkrama dengan warga atau panitia di masjid atau di sekitar rumah warga (wawancara, Mahammad Satir, 19 September 2013). Interaksi ini bermakna bahwa etnis Bugis masih memegang prinsip-prinsip budayanya. Budaya yang masih ditampakkan oleh etnis Bugis ini dikenal dengan Sipatuo dan Sipatokkong bermakna saling menghidupi dan saling membangun. Sebagaimana Abd Rahman Rahim dalam bukunya "Nilai-nilai Utama Kebudayaan Bugis" bahwa etnis Bugis memiliki nilai utama dalam budayanya, di antaranya adalah kejujuran (alempureng), kecendikiaan (amaccang), kepatuhan (asitinajang), keteguhan (agettengeng), usaha (reso), harga diri/malu (siri'), sipatuo dan sipatokkong (Rahim, 2011:81).

\section{Dimensi Sosial}

Pola interaksi sosial etnis Bugis dengan the others yang seagama dapat dijumpai pada aktivitas yang berdimensi hubungan sosial, bentuk interaksi ini dapat berbentuk pola hubungan pernikahan, pola hubungan partisipasi politik, dan pola hubungan aktivitas keagamaan. Pola interaksi etnis Bugis pada dataran dimensi sosial ini adalah, Pertama; pola hubungan pernikahan. Pernikahan merupakan pertemuan dua insan manusia dari unsur Adam dan Hawa. Pernikahan dua muda mudi tidak hanya melibatkan kedua insan tersebut, tetapi melibatkan keluarga besar kedua insan tersebut. Pernikahan dua insan beda etnis banyak dijumpai di Kota Sorong, sebagaimana yang dilakoni etnis Bugis menikahi gadis etnis pribumi Kota Sorong dari suku Moi sejak dahulu kala. Interaksi pernikahan yang ditampakkan etnis Bugis ini dapat dilihat dalam dua bentuk. Pertama adalah menikah dengan etnis pribumi dan yang kedua, menikah dengan sesama etnis pendatang. Pola pernikahan ini bermakna perwujudan filosofi Bugis perantau yang dikenal dengan Filosofi Tellu Cappa (Kusuma, 2010:15). Filosofi Tellu Cappa adalah filosofi "tiga ujung" yang telah ditampakkan pertama kalinya oleh lima bangsawan Bugis dari kerajaan Luwu pada abad
XVII. Cappa atau ujung pertama bermakna ujung lidah, artinya ketika etnis Bugis sedang melakukan diplomasi dan negosiasi kerja sama menggunakan bahasa yang santun. Cappa atau ujung kedua adalah ujung kelamin, maknanya ketika etnis Bugis ingin menyambung tali persaudaraan dengan etnis lain, mereka akan menikahi putri raja atau putri bangsawan dan juga putri masyarakat asli di daerah tersebut. Cappa atau ujung ketiga adalah ujung badik, simbol ini bermakna ketika etnis Bugis mempertahankan hak atau membela diri maka ujung badik atau senjata lain yang akan menjadi pilihan terakhir untuk menyelesaikan masalah. filosofi ini senantiasa melekat pada diri pribadi etnis Bugis ke mana pun merantau.

Pola interaksi etnis Bugis pada dataran dimensi sosial yang Kedua adalah pola hubungan partisipasi politik. Keterlibatan etnis Bugis dalam berbagai bidang di Kota Sorong sangat bervariatif, hal ini dapat diketahui misalnya dalam bidang politik. Etnis Bugis juga ikut berpartisipasi dalam bidang politik. Mereka tidak hanya berkumpul dalam satu partai politik, namun tersebar diberbagai parpol. Interaksi etnis Bugis dengan The others di bidang politik dapat dilihat dalam dua bentuk. Pertama, pada kegiatan formal, para anggota legislatif Kota Sorong melakukan rapat atau sidang. Kedua, pada kegiatan nonformal, para anggota legislatif biasa melakukan acara-acara secara pribadi dengan mengundang semua anggota DPR Kota Sorong berkumpul di rumah salah seorang anggota DPR. Meskipun berbeda etnis, mereka nampak akrab dan bercengkrama sambil menikmati hidangan yang disuguhkan oleh tuan rumah. Pada konteks ini menunjukkan bahwa etnis Bugis mampu beradaptasi dengan the others pada ranah politik, bahkan memperkuat ikatan emosional di antara mereka $(\mathrm{H}$. Nurdin Nawawi, wawancara, 16 November 2013). Dengan pola interaksi etnis Bugis dengan the others pada ranah politik ini dapat bermakna adanya rasa saling menghargai di antara anggota legislatif yang multietnis.

Pola interaksi etnis Bugis pada dataran dimensi sosial yang Ketiga adalah pola hubungan Aktivitas keagamaan. Aktivitas keagamaan di Kota Sorong merupakan kegiatan yang sedang berkembang, hal ini tampak pada banyaknya majelis taklim dan kelompok-kelompok pengajian di Kota Sorong. Selain rutinitas shalat berjamaah dan jumatan di masjid, juga terdapat kegiatan keagamaan dalam bentuk zikir dan tausiah di berbagai masjid. Tampak pada salah satu kegiatan zikir dan tausiah 
di masjid At-Taubah, jamaah yang terdiri dari etnis Bugis, Jawa, Ambon, Ternate dan lainnya sedang menikmati lantunan zikir yang dipimpin K.H. Uso salah seorang tokoh agama di Kota Sorong. Kegiatan keagamaan ini telah berjalan selama enam tahun yang rutin dilakukan pada Ahad malam. Kelompok pengajian ini mengadakan zikir bersama yang dilakukan di masjid-masjid Kota Sorong secara bergiliran setiap malam Senin. Aktivitas keagamaan ini dapat dilihat dalam berbagai bentuk. Pertama, melakukan ceramah agama di depan jamaah multietnis. Kedua, melakukan zikir bersama yang dipimpin oleh salah seorang jamaah.

Pola interaksi sosial etnis Bugis dengan the others yang seagama dapat dijumpai juga pada aktivitas yang berdimensi hubungan sosial, bentuk interaksi ini dapat berbentuk motif bisnis/ ekonomi, motif politik, dan motif sosial budaya. Motif Pertama, adalah sebagaimana kedatangan etnis Bugis di Kota Sorong, selain motif ekonomi juga karena menghindar dari peperangan saudara dan kekacauan di daerah Sulawesi Selatan (Amri dan Efendi, 2009:60). Etnis Bugis di Kota Sorong melakukan kegiatan ekonomi di berbagai bidang. Di antaranya menjadi seorang pedagang yang melakukan perdagangan di pasar, mall, atau kedai dan warung makan dan lainnya. Kegiatan ini merupakan usaha untuk menghidupi keluarganya atau penyambung hidup. Mereka berinteraksi dan mencari pelanggan dari berbagai etnis. Aktivitas perdagangan etnis Bugis di pasar Remu Kota Sorong sangat variatif. Mulai dari pedagang sembako, alat rumah tangga, kain, hingga terlibat dalam ekspor impor barang dan jasa. Aktivitas tersebut mejadikan etnis Bugis banyak berinteraksi dengan the others untuk menjaga kelangsungan bisnis tersebut. Hal ini menunjukkan bahwa dengan motif ekonomi, etnis Bugis menjaga keharmonisan dengan pelanggan dari berbagai etnis (Daswar, wawancara, tanggal 19 Oktober 2013). Motif ekonomi ini bermakna bahwa etnis Bugis sangat menjaga kerukunan dan keakraban agar pelanggan dari berbagai etnis tidak menjauh dari bisnisnya dan senantiasa tetap melakukan transaksi yang saling menguntungkan. Dampaknya adalah selain keharmonisan antar etnis juga transaksi perdagangan selalu terjaga untuk kelangsungan hidup antaretnis.

Motif Kedua adalah pada aktivitas yang berdimensi hubungan sosial, bentuk interaksi ini dapat berbentuk motif politik.Tidak sedikit etnis Bugis melakukan aktivitas yang dilandasi motif politik. Hal ini didasari pada kenyataan bahwa banyak partai yang melibatkan etnis Bugis dalam kegiatan kepartaian. Bahkan di Kota Sorong banyak etnis Bugis yang menjadi calon legislatif periode 2014-2019 yang tersebar diberbagai parpol. Untuk mendapatkan simpati masyarakat Kota Sorong, para kandidat calon legislatif banyak melakukan kegiatan bernuansa sosial. Beberapa bentuk di antaranya, Pertama, para kandidat calon legislatif melakukan kunjungan di kampus perguruan tinggi dengan mengadakan seminar atau sosialisasi. Kedua, melakukan bakti sosial dengan memberi bantuan kepada fakir miskin. Ketiga, mengunjungi rumah sakit dan menjenguk para pasien rawat inap di beberapa rumah sakit yang ada di Kota Sorong. Keempat, mengadakan kunjungan silaturrahmi secara personal kepada para tokoh masyarakat atau kepala suku. Kelima, memasang baliho caleg di beberapa titik lokasi yang mudah dilihat masyarakat Kota Sorong. Aktivitas ini bermakna bahwa etnis Bugis proaktif menggalang simpati masyarakat multietnis dalam mencari dukungan politik dalam rangka berjuang ke arah kehidupan masyarakat Kota Sorong yang lebih baik.

Motif Ketiga adalah motif sosial budaya yang tampak pada adanya beberapa di antara kelompok masyarakat atau etnis di Kota Sorong masih tergolong masyarakat kurang mampu dan bahkan terpinggirkan. Etnis Kokoda adalah salah satu etnis yang masih tergolong tertinggal dan terpinggirkan terutama yang berada di kawasan kilo meter 7 Kota Sorong. Hal ini membuat sebagian masyarakat baik sebagai organisasi, institusi maupun secara personal turut prihatin dengan keadaan tersebut. Etnis Bugis sebagai salah satu di antara kelompok masyarakat yang sering memberi bantuan kepada etnis Kokoda dalam bentuk materil maupun moril. Bantuan tersebut dapat berupa dana atau bantuan pendidikan dan pemberdayaaan perekonomian etnis Kokoda. Sebagaimana diinformasikan oleh kepala suku Kokoda Idris Wugaje bahwa, mereka sering datang mengunjungi kami dan memberi bantuan (Idris Wugaje, wawancara tanggal 18 November 2013). Hal ini menunjukkan bahwa beberapa personal etnis Bugis melakukan aktifitas sosial kemanusiaan. Apa yang ditampakkan etnis Bugis dapat bermakna bahwa etnis Bugis masih berpegang pada prinsip budayanya Sipatuo Sipatokkong yaitu saling menghidupi dan saling membangun di antara sesama manusia (Rahim, 2011:81). 
Pola Interaksi Sosial etnis Bugis dengan The Others yang tidak seagama

\section{Jalin Kerja Sama Lintas Umat}

Aktivitas keagamaan merupakan sebuah bentuk kegiatan yang dilandasi nilai-nilai normatifitas keagamaan yang berwujud pada realitas kehidupan etnis Bugis yang dilakukan sehari-hari.Bentuk aktivitas keagamaan ini dapat dilihat pada kegiatan silaturrahim, kegiatan pada hari lebaran dan perayaan hari-hari besar Islam lainnya. Karenanya etnis Bugis dalam melakukan aktivitas keagamaan dapat dilihat sebagai berikut;

Pertama, silaturrahim. Silaturrahim merupakan sebuah gerakan individu atau kelompok yang bertujuan untuk menyambung keakraban antara manusia. Selain itu silaturrahim juga dapat menjalin kerja sama lintas umat. Silaturrahim yang ditampakkan oleh etnis Bugis di Kota Sorong dapat dilihat dalam beberapa bentuk, seperti berkunjung ke rumah tetangga yang non muslim atau pun dikunjungi. Hal ini terjadi tidak hanya pada hari raya idul fitri atau hari natal dan tahun baru, namun hari-hari biasa pun masih saling mengunjungi. Faktor konteks sosial menjadi indikasi kuatnya entitas ini bersatu dan senantiasa menjalin silaturrahim di antara mereka. Hal ini dikuatkan oleh Kepala P3M STAIN Sorong dalam sebuah wawancara, dikatakan bahwa etnisitas dapat kuat ketika terjalinnya interaksi antar etnis (Muhammad Rais, wawancara, 4 November 2013). Hal ini berarti bahwa silaturrahim menjadi kuat ketika etnisitas itu terjalin interaksi di antara mereka. Maka implikasinya sebuah kerukunan akan tercipta dan tatanan sosial berjalan dengan kondusif.

Kedua, lebaran. Lebaran oleh umat Islam merupakan hari raya kemenangan setelah mereka melakukan ibadah puasa selama sebulan penuh. Puasa tidak hanya menahan lapar dan haus, namun juga menahan dari perbuatan-perbuatan yang tidak berguna, termasuk menceritakan aib saudaranya, menghindari pembicaraan kotor dan mencaci maki. Ketika hari lebaran idul fitri, umat muslim saling mengunjungi keluarga, teman dan para tetangga untuk saling maaf memaafkan dalam suasana gembira. Bahkan mereka mengundang dan menerima tamu dari sahabat dan tetangga non muslim. Konteks sosial ini menjadi indikasi kuatnya hubungan etnis Bugis dengan theothers yang tidak seagama. Hal ini diungkapkan oleh Agustinus, tokoh masyarakat agama Katolik Kota Sorong, bahwa "sesungguhnya orang Bugis sangat familiar dalam bergaul dengan masyarakat kita.
Bahkan kami sering diundang buka puasa bersama, mereka terkesan sangat baik tanpa membedabedakan agama kami.Sehingga kami juga merasa nyaman berteman dengan orang Bugis.Kalau hari lebaran kami juga berkunjung ke rumah orang Bugis sebagai penghormatan dan pertemanan kepadanya" (Wawancara, 22 November 2013).

Ketiga, hari besar Islam. Hari-hari besar Islam biasanya diperingati oleh umat muslim di seluruh dunia, namun bentuk perayaannya berbeda-beda. Perbedaan ini dimungkinkan karena faktor budaya masing-masing daerah. Salah satu hari besar Islam misalnya, tanggal 12 Rabiul Awal yaitu hari kelahiran nabiyullah Muhammad saw, dikenal juga sebagai Hari Maulid Nabi. Peringatan Hari Maulid Nabi Muhammad saw, pertama kali diselenggarakan oleh Sultan Shalahuddin Al-Ayyubi ketika menghadapi pasukan salib yang pasukannya berasal dari seluruh daratan Eropa Pimpinan Richard "Si Hati Singa". Pada acara peringatan Maulid Nabi itu diceritakan kembali riwayat kelahiran dan perjuangan Nabi Muhammad saw. yangpatut diteladani. Acara tersebut bertujuan untuk mengobarkan semangat perjuangan dan pengorbanan pasukan Saladin untuk membela dan menyelamatkan Islam. Terbukti Shalahuddin berhasil membawa pasukannya memasuki Yerussalem.

Bagi etnis Bugis memperingati Maulid Nabi sudah menjadi tradisi di kampung Sulawesi. Peringatan Maulid Nabi Muhammad saw. diselenggarakan dengan sangat meriah. karena selain ceramah agama juga dimeriahkan dengan banyaknya makanan dan kue khas daerah. Telur yang dihiasi dengan warna yang menarik dijejer dan disusun bergantungan diujung lidi yang tertancap pada batang pisang hias. Usai acara, telur itu menjadi rebutan bagi anak-anak dan menjadi ajang permainan yang meriah. Kemeriahan peringatan Maulid Nabi Muhammad saw tidak hanya dirasakan oleh etnis Bugis saja, tetapi juga ikut dirasakan oleh etnis lain bahkan masyarakat non muslim. Kue dan makanan dibagikan pada masyarakat, bukan hanya dibagikan pada sesama etnis Bugis tetapi juga kepada etnis lain bahkan tidak terkecuali masyarakat non muslim. Konteks ini menjadi faktor kuatnya rasa toleransi dan rasa kebersamaan etnis Bugis pada masyarakat sekitar. Sebagaimana diakui oleh Agustinus, tokoh masyarakat agama Katolik Kota Sorong, bahwa "orang Bugis ketika mengadakan peringatan hari besar Islam, mereka juga mengundang kami yang non muslim, bahkan juga memberi kami makanan dan kue-kue khas 
Bugis, hal ini menjadi kesan tersendiri bagi kami bahwa orang Bugis itu bersifat terbuka dan toleran terhadap kami"(wawancara, 22 November 2013).

\section{Organisasi Masyarakat}

Menjalin kerja sama lintas umat, etnis Bugis melakukannya dengan melalui media forum masyarakatan atau organisasi masyarakat, di antaranya adalah Forum Komunikasi Umat Beragama dam Majelis Ulama Indonesia.

Pertama, Forum Komunikasi Umat Beragama (FKUB) dibentuk berdasarkan Peraturan Bersama Menteri Agama dan Menteri Dalam Negeri Nomor 9 dan Nomor 8 Tahun 2006. Kerukunan umat beragama adalah keadaan hubungan sesama umat beragama yang dilandasi toleransi, saling pengertian, saling menghormati, menghargai kesetaraan dalam pengamalan ajaran agamanya dan kerjasama dalam kehidupan bermasyarakat, berbangsa dan bernegara di dalam Negara Kesatuan Republik Indonesia berdasarkan Pancasila dan Undang-Undang Dasar Negara Republik Indonesia Tahun 1945. Ada beberapa tugas FKUB di antaranya adalah a. Melakukan dialog dengan pemuka agama dan tokoh masyarakat; b. Menampung aspirasi ormas keagamaan dan aspirasi masyarakat; c. Menyalurkan aspirasi ormas keagamaan dan masyarakat dalam bentuk rekomendasi sebagai bahan kebijakan bupati/walikota. FKUB Kota Sorong telah beberapa kali melakukan programprogram dalam rangka sosialisasi kerukunan umat dan menjalin harmonisasi antar umat beragama. Interaksi etnis Bugis dengan the others dapat dijumpai dalam beberapa bentuk, pertama adalah melalui pertemuan antar tokoh agama, kedua adalah melalui program sosialisasi kerukunan antar umat beragama. Konteks ini menunjukkan harmonisasi interaksi antar umat yang dilakukan di dalam gereja. Mereka saling menghormati agama masing-masing. Sebagaimana kesan Agustinus, bahwa orang Bugis sangat toleran dan memiliki rasa solidaritas yang tinggi dengan agama lain dan dapat menjalin komunikasi dengan baik terhadap orang yang berbeda agama (wawancara, 22 November 2013).

Kedua, Majelis Ulama Indonesia (MUI). Keberadaan MUI yang bertujuan untuk mewujudkan masyarakat yang berkualitas (khaira ummah), dan negara yang aman, damai, adil dan makmur rohaniah dan jasmaniah yang diridhai Allah swt. (baldatun thayyibatun wa rabbun ghafur). Untuk mencapai tujuannya, MUI melaksanakan berbagai usaha, antara lain memberikan bimbingan dan tuntunan kepada umat, merumuskan kebijakan dakwah Islam, memberikan nasehat dan fatwa, merumuskan pola hubungan keumatan, dan menjadi penghubung antara ulama dan umara. MUI Kota Sorong menyadari bahwa masyarakat Kota Sorong terdiri dari berbagai agama, etnis dan budaya. Masyarakat yang pluralis dan multikultur itu sangat berpotensi terjadinya konflik agama, ras dan bahkan konflik antar etnis. Karenanya untuk mengantisipasi terjadinya konflik MUI Kota Sorong berupaya menjalin bekerja sama dengan pemerintah, menjalin komunikasi dengan berbagai tokoh agama, tokoh masyarakat dan masyarakat Kota Sorong. MUI adalah organisasi yang memiliki anggota dari berbagai organisasi masyarakat Islam, di antaranya adalah Muhammadiyah dan NU. Selain itu anggota MUI terdiri dari berbagai etnis Muslim, salah satu di antanya adalah etnis Bugis. Pola interaksi etnis Bugis yang ditampakkan pada organisasi ini ada dua bentuk, yaitu bentuk interaksi internal sesama anggota MUI dan bentuk interaksi eksternal anggota MUI. MUI dalam menyelesaikan kasus konflik agama senantiasa bekerja sama dengan pemerintah, tokoh agama dan tokoh masyarakat. Sebagaimana dituturkan oleh ketua MUI Kota Sorong, Abdul Mannan Fakaubun (etnis Ternate keturunan Bugis), bahwa baru-baru ini terjadi kesalahpahaman antar remaja non muslim dengan pihak pengurus masjid di Kampung Baru. Persoalan itu akhirnya didamaikan hingga terhindar dari konflik yang lebih besar (wawancara, 18 Februari 2013).

\section{Kehidupan Masyarakat}

Pola interaksi sosial etnis Bugis pada kehidupan masyarakat Kota Sorong dapat dilihat pada upaya etnis Bugis dalam mengonstuksi sebuah kohesi sosial yang kuat dalam kehidupan masyarakat pada aspek sosial, ekonomi dan budaya. Pola konstruksi kohesi sosial masyarakat tersebut dapat dilihat sebagai berikut:

Hubungan Sosial. Hubungan Sosial merupakan hubungan timbal balik antara individu dengan individu yang lain, Saling mempengaruhi dan didasarkan pada kesadaran untuk saling menolong. Selain itu hubungan sosial juga dapat disebut sebagai interaksi sosial. Interaksi sosial adalah proses saling memengaruhi di antara dua orang atau lebih. Interaksi sosial dalam masyarakat berlangsung antar komponen baik secara individual, kelompok, maupun lembaga (Soekanto, 1993: 245- 
247). Mereka hidup saling membutuhkan, saling mempengaruhi, saling menjaga dan menghargai dalam harmonitas yang terbina berdasarkan nilai dan norma yang berlaku.

Hubungan sosial etnis Bugis dengan the others di Kota Sorong nampaknya sangat harmonis sebagaimana diakui oleh ibu Supriaty bahwa "orang Bugis pandai berdagang, kalau di Kota Sorong ini mereka lebih dominan dalam perdagangan, mereka juga pintar mengambil hati orang-orang. Saya juga pernah tinggal sekompleks dengan orang Bugis, seperti istrinya pak Hermanto (Rektor UMS) mereka baik dan pandai bergaul" (wawancara, 7 Desember 2013).

Ikatan perkawinan. Pernikahan merupakan pertemuan dua insan manusia dari unsur pria dan wanita. Pernikahan dua muda mudi tidak hanya melibatkan kedua insan tersebut, tetapi melibatkan keluarga besar keduanya. Ikatan perkawinan kedua insan ini akan menjadikan kedua keluarga tersebut makin mempererat hubungan kekeluargaan kedua belah pihak. Pernikahan dua insan beda etnis banyak dijumpai di Kota Sorong, sebagaimana juga banyak terjadi di kota lainnya. Meski jarang terjadi namun ada etnis Bugis yang menikah dengan etnis Papua pesisir, sebagaimana dituturkan oleh Sarah (masyarakat asli Papua), "saya pernah lihat orang Bugis kawin dengan orang Papua Pesisir/Seget, tapi itu baru sekali saja, yang banyak kawin dengan orang Papua di sini orang dari Jawa. Waktu orang Bugis kawin dengan orang Papua, acara adat yang dipake adat Papua, tapi malam sebelum acara nikah saya lihat pake acara mappaccing, saya tau itu adat Bugis" (wawancara, 21 November 2013). Pernikahan dengan menggunakan adat masing-masing mempelai merupakan simbol saling menghargai kultur daerah asal mempelai, selain itu merupakan perekat dan penyatuan dua unsur budaya yang berbeda menjadi satu padu yang tak terpisahkan. Ikatan pernikahan ini juga merupakan simbol ikatan penguat hubungan sosial antar dua keluarga besar yang mewakili etnis atau suku masing-masing bila kedua mempelai berbeda etnis. Hubungan sosial dalam bentuk ikatan perkawinan dapat bermakna simbol kuatnya integrasi hubungan masyarakat. Kerukunan tetangga. Kota Sorong merupakan Kota terpadat kedua di Papua setelah Kota Jayapura atau menjadi kota terpadat di Papua Barat. Sehingga tidak berlebihan jika Bapak Wali Kota Sorong Drs. Lambert Jitmaw, M.Si menganggap bahwa Sorong adalah miniatur kota Indonesia, karena hampir seluruh etnik Indonesia ada di kota ini yang hanya merupakan kota kecil, bahkan kota terkecil di Indonesia (Sambutan pada peletakan batu pertama pembangunan gedung STAIN Sorong tanggal 27 Oktober 2013). Pernyataan Wali Kota Sorong tersebut tidak berlebihan melihat suasana kota ini yang majemuk. Hampir seluruh etnik ada di kota ini, hal ini dapat dilihat dari beberapa wilyah pemukiman penduduk. Dalam satu wilayah lingkungan kelurahan nampak perumahan penduduk berjejer dalam berbagai bentuk dan ukuran. Rumah-rumah yang ada di setiap wilayah pemukiman penduduk dihuni tidak hanya dimonopoli oleh etnis tertentu, namun dihuni oleh berbagai etnis. Wilayah pemukiman penduduk warga masyarakat Kota Sorong hampir semuanya hidup secara berdampingan dengan berbagai etnis (Musdalifah, wawancara 20 Oktober 2013). Hubungan sosial etnis Bugis dengan etnis lain dalam wilayah pemukiman yang sama adalah hubungan pertetanggaan. Tetanggan bagi Etnis Bugis harus dihormati dan dihargai sebagaimana layaknya keluarga dan saudara dan memiliki hak hidup layak seperti masyarakat lainnya. Sikap orang Bugis ini didasari oleh budayanya dengan prinsip "sipakatau" dan prinsip "di mana bumi dipijak di situ langit dijunjung" (Rahim, 2011: 1-7). Prinsip budaya sipakatau bermakna kewajiban menghargai setiap orang yang juga hidup berbudaya di muka bumi dan senantiasa tunduk pada aturan atau adat setempat. Prinsip ini merupakan sikap yang diaplikasikan oleh etnis Bugis dalam bermasyarakat di Kota Sorong, sehingga mereka dapat diterima di tengah-tengah masyarakat Papua dan etnis lainnya. Faktor konteks hubungan sosial terutama hubungan yang harmonis dengan tetangga menjadi indikasi kuatnya entitas ini bersatu dan senantiasa menjalin silaturrahim di antara mereka.

\section{PENUTUP}

Berdasarkan hasil penelitian yang telah dikemukakan maka dapat diambil kesimpulan bahwa pola interaksi sosial etnis Bugis Makassar dapat dilihat pada interaksi sosial etnis Bugis dengan the others yang seagama dan interaksi sosial etnis Bugis dengan the others yang tidak seagama.

Interaksi sosial etnis Bugis dengan the others yang seagama di Kota Sorong dapat dilihat; Pertama pada aktivitas ritual keagamaan, aktivitas ini biasanya dilakukan oleh etnis Bugis dalam bentuk pengajian dan Kegiatan hari raya besar Islam. Kedua, pada dimensi sosial. Pada dimensi ini terjadi pola hubungan sosial dalam bentuk adanya ikatan 
pernikahan antar etnis yang seagama. Hubungan sosial juga dapat dilihat pada aktivitas partisipasi politik, selain itu juga pada hubungan sosial keagamaan. Ketiga, pada aktor personal. Aktivitas personal dapat dilihat pada sosok pribadi etnis Bugis ketika menjadi seorang politikus, pengusaha, pedagang dan sebagai tokoh masyarakat. Pola hubungan personal ini juga dapat dilihat pada hubungan kekeluargaan seperti keramahan, saling membantu dan saling menghormati.

Interaksi sosial etnis Bugis dengan the others yang tidak seagama dapat dilihat; Pertama, menjalin kerja sama lintas umat. Hal ini dapat dilihat pada aktivitas keagamaan pada hari raya, di sini etnis Bugis berinteraksi dengan the others yang tidak seagama dalam bentuk silaturrahim dengan melakukan kunjungan. Kerja sama lintas umat juga dilakukan pada forum organisasi misalnya pada Forum Komunikasi Umat Beragama dan Majelis Ulama Indonesia. Kerja sama lintas umat juga dapat dilihat pada upaya etnis Bugis dan the others yang tidak seagama dalam meredam konflik, baik konflik antar etnis, konflik agama maupun konflik yang bersifat individu atau keluarga. Kedua, mengonstruksi kohesi sosial. Etnis Bugis dapat membangun sebuah hubungan dalam kehidupan masyarakat pada aspek sosial, ekonomi dan budaya. Ketiga, menciptakan lingkungn kondusif. Etnis Bugis dapat menciptakan lingkungan kondusif pada komunitas keluarga dengan menguatkan ikatan emosional kekeluargaan, mengedepankan sikap moralitas dan berinteraksi dengan pola keterbukaan.

Potensi konflik di Kota Sorong memungkinkan terjadi, namun potensi konflik tersebut masih dapat diredam dengan melihat pola interaksi yang dibangun etnis Bugis dengan the others atau etnis pendatang dengan etnis lain di bumi Papua. Konflik yang selama ini terjadi di Kota Sorong memang ada namun sifatnya insidentil dan kriminal biasa yang tidak berpotensi menjadi konflik yang besar.

\section{UCAPAN TERIMA KASIH}

Tulisan yang ada di tangan pembaca ini merupakan karya yang tidak terlepas dari bantuan dan masukan berbagai pihak, olehnya itu terima kasih penulis haturkan kepada informan penulis dalam penelitian diantaranya Bapak Wali Kota Sorong, H. Supran, Hj. Fatimah, Bapak Hasyim Anas, Bapak Muhamad Satir, H. Nurdin Nawawi, KH. Uso, Bapak Daswar, Bapak Idris Wugaje, Bapak Muhammad Rais, Bapak Agustinus, Bapak Abd. Mannan Fakauban, Ibu Supriaty, Ibu Sarah, Ibu
Musdalifah dan semua informan yang tidak dapat penulis sebutkan. Ucapan yang sama penulis kepada Tim Redaksi Al-Qalam yang telah menjadikan tulisan ini sebagai salah satu dalam terbitan edisi ini.

\section{DAFTAR PUSTAKA}

Amri, Irham dan Efendi Bakhtiar. 2009. Bugis di Balikpapan Menelusuri Jejak dan Peranan Bugis Makassar di Balikpapan. Cet. I. Balikpapan: Team Publication of Balikpapan.

Badan Pusat Statistik Kota Sorong Tahun 2010 dan Tahun 2012

Bappeda Kota Sorong. 2004. Profil Kota Sorong

Campbell, Tom. 1981. Seven Theories Of Human Society.Clarendon Press, Oxford University Press, Walton Street. Diterjemahkan oleh F. Budi Hardiman. 1994, dengan judul Tujuh Teori sosial. Cet. VI. Yogyakarta: Kanisius.

Creswell, Jhon W. 2010. Research Design Pendekatan Kualitatif, kuantitatif dan Mixed. Cet. I. Yogyakarta: Pustaka Pelajar.

Hakim, Bashori A. 2006. Konflik dan Resolusi Damai. Harmoni, 5/18.

Haryanto, Sindung. 2012. Spektrum Teori Sosial Dari Klasik Hingga Postmodern, Cet. I. Jogjakarta: Ar-Ruzz Media.

Kusuma. I.C, Andi Ima. 2010. Politik Ranjang Bugis Makassar. (Pidato pengukuhan guru besar Universitas Negeri Makassar.

Lubis, Ridwan, ed. 2005. Meretas Wawasan \& Praksis Kerukunan Umat Beragama di Indonesia. Cet.I. Jakarta: Puslitbang Kehidupan Beragama.

Mattulada dalam Koentjaraningrat. 1999. Manusia dan Kebudayaan Indonesia. Cet. VIII. Jakarta: Djambatan.

Mustafa, Bisri \& Elisa Vindi Maharani. 2011. Kamus Lengkap Sosiologi. Cet. III. Jogjakarta: Panji Pustaka.

Nawawi, Imam. 2010. Riyadhus Shalihin. Cet. III. Jakarta: AkbarMedia.

Pusat Bahasa Departemen Pendidikan Nasioal. 2008. Kamus Bahasa Indonesia Jakarta: Pusat Bahasa.

Rahim, Abd. Rahman. 2011. Nilai-Nilai Utama Kebudayaan Bugis. Cet. I, Yogyakarta: Ombak.

Ritzer, George. 2011. Sociological Theory. New York: Published by McGraw-Hill. Diterjemahkan oleh Saut Pasaribu, Rh.Widada, dan Eka 
Adinugraha 2012, dengan judul Teori Sosiologi dari Sosiologo Klasik Sampai Perkembangan Terakhir Postmodern. Cet. I. Yogyakarta: Pustaka Pelajar.
Soekanto, Soerjono. 2000. Sosiologi Suatu Pengantar. Cet. XXX. Jakarta: RajaGrafindo.

Sugiyono. 2011. Metode Penelitian Kuantitatif, Kualitatif dan ReD.Cet. XIV. Bandung: Alfabeta. 